\title{
The Development Model Coaching of Karate Club in the Junior High School of Medan City
}

\author{
Suryadi Damanik ${ }^{1}$, Suprayitno $^{2}$, Zulfan Heri $^{3}$ and Puji Ratno ${ }^{4}$ \\ \{Suryadi66@gmail.com ${ }^{1}$, supra.yt@gmail.com ${ }^{2}$, zulfanheri67@yahoo.com ${ }^{3}$, pujiratno@ unimed.ac.id ${ }^{4}$ \} \\ Department Of State University Of Medan, Indonesia ${ }^{1,2,3,4}$
}

\begin{abstract}
Karate is one of the fastest growing branches of martial arts in Indonesia and in North Sumatra Province. The karate sports is one of the flagship sports branches of North Sumatera Province which is able to produce achievements in every sporting event. Lately, the achievement of the karate sport is stagnant and tends to experience a decline in achievement. The lack of achievement is certainly due to the ineffectiveness of existing coaching models. Based on observations, and interviews with coaches of Karate clubs in Medan's First junior High School, information was obtained that the coaching model running in the Medan City Karate Club was not uniform and not well organized. This research includes the type of research and development (research and development) or more often abbreviated as R and D. This research took place in 3 years, where the first year was focused on organizational arrangement and the development of talent identification tools. In the second year, priority will be given to structuring the quality of the training which in this case is focused on the design of the karate club curriculum. Whereas in the third year it is targeted for structuring the competition system. Broadly speaking, each year the research goes through 3 stages, namely (1) the preliminary study phase, (2) the drafting stage, (3) the testing phase. The population in this study is the Junior Karate Club registered in the Medan City Branch Management. This research activity has also resulted in the organizational structure of the karate club, the talent scuoting of karate instrument, and the karate club curriculum.
\end{abstract}

Keywords: Coaching Model,School Karate Club

\section{Introduction}

The martial arts branch, karate originating from Japan is very rapidly developing in Indonesia. This is marked by the many standing karate college associations that exist in Indonesia and proved to be held many tournaments between regional and international levels. To improve sports performance, especially in the karate sport, training is needed that can improve all components of the physical condition, because the physical condition component, which is prime, determines the level of achievement.

At first people only develop the skills of the hands, feet, and his body's ability to fight for life to earn a living or to defend themselves. Physical ability and martial skills in modern life are very necessary for humans. Many types of martial skills have been successfully developed by humans and learned from generation to generation such as: martial arts, karate, kungfu, taekwondo, kempo, judo, boxing and others.

Karate should not be viewed merely a technique to fight alone, because in fact the karate has meaning far beyond self-defense. Karate is a way of living a life whose purpose is to give 
the possibility for someone to be able to realize their potential, both physically and spiritually. If the spiritual aspect of Karate is ignored, the physical aspect is meaningless.

Aside from being a martial arts sport, karate is also one of the sports achievements. The numbers competed in karate are two, namely kumite and words. Kumite is a number that matches one-on-one battles in an arena that is 8 by 8 meters wide, individually and in teams with the time and rules set by PB FORKI in 2012. Words are numbers that compare various forms of form in an arena that is 8 times 8 meters, individually or in teams (consisting of 3 people) according to the age class that is followed and the rules set by PB FORKI.

Basically every Kohai (student) who practices for achievement gets the same teaching and training with each other both for kumite and for words. Someone who can do kumite well not be able to perform the movement of said well too, but when it can be said with good movement is certainly someone that can do a good kumite movement. Because all kumite attack movements are contained in words, it's just that the word is a series of movements that must be demonstrated sequentially with the right form and rhythm so to be able to do the word must have a strong memory. The word in karate is divided into several parts, namely basic words, sithe kata, and tokui words. The basic words consist of Taikyoku (Shodan, Nidan, and Sandan), Heian (Shodan, Nidan, Sandan, Yondan, and Godan). (source: Eka, Widya. Indonesian Karate-Do Institute (1996: 1). 26 Shotokan Karate Skills).

Karate is one of the fastest growing branches of martial arts in Indonesia and in North Sumatra Province. The karate sports branch is one of the flagship sports branches of North Sumatra Province which is able to produce achievements in every sporting event. Lately, the achievement of the karate sport is stagnant and tends to experience a decline in achievement.

The lack of achievement is certainly due to the ineffectiveness of existing coaching models. Based on observations, and interviews with coaches of Karate clubs in Medan's First High School, information was obtained that the coaching model running in the Medan City Karate Club was not uniform and not well organized.

\section{Manuscript Preparation}

\subsection{Karate}

Karate entered Indonesia was brought by students studying in Japan, and in 1963 in Jakarta the first Dojo was established from the Shoto-kan school with its founding figures: Baut Adikusumo, Karyanto, and Muchtar. Then the wadokai flow was introduced in Indonesia by Ir. H. Chaerul. A. Taman in 1970, who had studied karate for 8 (eight) years living in Japan (1962-1970). Furthermore, according to Ivan Yulivan, (2012: 13). Karate sports have a rule that is always followed by karateka, both before and after carrying out an exercise activity, tests, demonstrations, and matches. Being a member or student of a karate college, one must understand and accept and implement sapta prasetia karate. In learning karate must be a warrior spirit, according to the origin of the word itself, namely "kara" means without using anything, and if it is deepened it literally comes from the words "Kara", "Te", and "Do" which have the meaning of the road / teachings with empty hands.

According to Abdul Wahid in Shotokan's book (2007: 1) "Karate is martial arts without using weapons, literally Karate-do comes from the words" Kara "," Te ", and" Do ".

So overall karate-do has meaning or is a way or teaching with bare hands that aims to improve personal discipline and form a whole person ". 
Karate training material is divided into 3 groups, namely:

1. Kihon (basic movement)

a. Dachi (easel)

b. Uke (rattling)

c. Tsuki (punch)

d. Uchi (sabetan)

e. Geri (kick)

\subsection{Kumite (Fighting)}

Based on the basic movements in kihon, in this section trained the role of basic movements to fight the enemy both in defense and attack.

\section{$2.3 \quad$ Word}

Literally the word means form / form / piece / pattern. In Budo the word is more interpreted as a form of special training that is the essence of a type. Martial arts that are displayed in a series of several kihon fruit arranged in such a way as in a standardization.

Currently karate has been used as a means of competition with two tournaments, namely kumite and the word along with the word application. In kumite someone fights with an opponent. Meanwhile, the word is an official form of training that combines basic karate techniques, such as punching, kicking, defending, and parrying in a set of defined movements. The word combines attacking and defending techniques, appropriate body movements and changes in direction. The word teaches karateka to face many attackers from at least four directions. The tournament began with the formation of the Japan Karate Association (JKA) and Masatoshi Nakayama was the person who introduced this concept.

According to J.B. Sujoto (Technique of Oyama Karate Series Kihon, 2002), the term Karate is written in modern Japanese letters which literally means empty-handed, has the following meanings:

a. Karate is a technique to defend yourself with bare hands or without weapons.

b. Karate also means an empty, clean soul without bad thoughts or self-interest, so that with a clean soul it allows one to learn and understand karate correctly.

\subsection{School Karate Club}

Regulation of the Minister of Education and Culture of the Republic of Indonesia number 62 of 2014, concerning extracurricular activities in elementary and secondary education, in article one paragraph 1 stated that extracurricular activities are curricular activities carried out by students outside of study hours, intra-curricular activities and kokurikuler activities in under the guidance and supervision of education units ". Article 2 states that the purpose of extracurricular activities is to optimally optimize the potential, talents, interests, abilities, personality, cooperation, and independence of students in order to support national education planning.

The school karate club is an activity formed in order to implement the education and culture minister's regulations on extracurricular activities. Where every school or education unit must provide a training forum to optimally optimize the potential, talents, interests, abilities, personality, cooperation, and independence of students in order to support national 
education planning. This is in line with the program of the Ministry of Youth and Sports where it is expected that sports athletes will emerge from sports clubs in schools.

One of the extracurricular activities in schools in Medan City is an extracurricular activity in the karate sport. With the formation of karate clubs in school schools, the martial arts talents in schools can be channeled through karate activities. So that the function of karate extracurricular activities can really benefit school children in developing their interests and talents.

\subsection{The Meaning Of Development}

Edwin B. Flippo defines development as follows: "Education is related to increasing general knowledge and understanding of our environment as a whole". While Andrew F. Sikula defines development as follows: "Development refers to the problem of staff and personnel is a long-term education process using a systematic and organized procedure by which managers learn conceptual and theoretical knowledge for general purposes".

So, Development is an effort to improve the technical, theoretical, conceptual and moral skills of employees in accordance with the needs of work / position through education and training. Education enhances employee theoretical, conceptual, and moral skills, while training aims to improve technical skills in the implementation of employee work, workshops for employees can increase more knowledge outside the company.

\subsection{Coaching}

Etymological guidance comes from the word bina. Coaching is the process, making, way of coaching, renewal, business and actions or activities that are carried out efficiently and successfully well. In the implementation of the concept of coaching should be based on the things that are effective and pragmatic in the sense that they can provide the best solution to the problems faced, and are pragmatic in the sense of basing the facts according to reality so that they are useful because they can be applied in practice.

Besides that conceptually, coaching or empowerment, comes from the word 'power' (power or empowerment). Therefore, the main idea of coaching is in touch with the concept of power. According to Wiranto (1999), coaching is an effort to increase the capacity of the community and provide the widest possible opportunity for the poor category population to carry out productive socio-economic activities so as to be able to produce higher added value and greater income. Thus, Sports coaching is essentially directed to increase access for individuals, families and community groups to the resources to carry out the production process and business opportunities. To be able to achieve this, various efforts are needed to motivate in the form of, among others, capital assistance and human resource development.

\subsection{Sports Coaching}

Almost all countries in the world have a pyramid-based sports coaching system, which follows the coaching stages which are based on pyramid theory, including; production, nursery, and improvement of achievement which is a series of phased, integrated, directed and continuous activities. The three elements above are interrelated and cannot be separated. The pyramid-based coaching system is a tiered sports coaching from the lower layer which is preparation, then continued continuously to the middle layer, nursery, continues to level up to the top of the pyramid, achievement development. 
More details on achievement sports coaching involves a number of key components. The results of international research reveal that there are at least 10 components (pillars) that must receive attention in conducting coaching. The ten pillars are; (1) financial support , (2) organization and structure of integrated sports policy, (3) foundation and participant, (4) achievement and identification development, (5) fostering elite performance, (6) sports infrastructure, (7) providing trainers, training and training quality, (8) the quality of national and international competition, (9) scientific research, (10)elite sport environment, media and sponsorship (Rusli Lutan: 2013: 33)

The direct results of the coaching process are maximum achievements in which all abilities both physical aspects, technical aspects, tactics and mentality work well. The purpose of sports is the development and development of sports is part of efforts to improve the quality of Indonesian people aimed at improving physical and spiritual health throughout the community, fostering character, discipline and sportsmanship, as well as developing sports achievements that can arouse a sense of national pride (GBHN, 1988).

\section{$3 \quad$ Research Methods}

\subsection{Development Models}

This study focused on developing a school Karate Club development model consisting of 3 stages. The three stages are (1) the organizational structure structuring stage and the development of talent identification tools (2) the curriculum structuring stage and the training method (3) structuring the competition system. This study takes three years, where the first year is targeted to produce organizational structures and measuring instruments talent identification, while the second year is prioritized for structuring curriculum and training methods, as well as the third year of structuring the competition system.

The research method used in an effort to answer the problem of this research is research and development which is often abbreviated as R \& D. Borg and Gall (1989: 784-785) describe ten steps in research and development. However, in this case, the Borg and Gall development research model was modified into three steps, namely: (1) the preliminary study phase, which included literature studies, field studies, and drafting of coaching models; (2) the model development stage, (3) the testing phase of the coaching model. In this case, the research model for the development of Borg and Gall was modified into three steps, namely: (1) the preliminary study phase, which included literature studies, field studies, and drafting a coaching model; (2) the development study phase, the drafting of the coaching model for experts related to karate and experts, an evaluation and improvement of the draft development model according to the input provided; present draft improvement of the coaching model to experts, evaluate and improve draft coaching models according to input from dynamic groups to design coaching models that will be tested; (3) Testing phase of the coaching model, by conducting a quasi experiment of one group pretest-posttest design. (Moleong: 2003).

\subsection{Development Procedure}

The steps of development research taken in this study are as follows; (1) preliminary study phase, (2) development phase, (3) trial phase. This is done both for year I, year II and year III. 


\subsection{Product Trial}

Trial Design

The design used in this study includes 3 main steps, namely preliminary studies, development of coaching models, and piloting of coaching models. Every major step there are several steps in it.

\subsection{Data Collection Instrument}

Data obtained from observation, interviews, documentation and test results. To maintain objectivity, observations are carried out by trainers, observers and researchers by utilizing the observation sheets that have been provided. To complete the data, discussions with trainers, observers and experts are carried out.

\section{$4 \quad$ Research Result}

In accordance with the first year research stage in this research activity, the research activities have resulted, among others.

1. The organizational structure of a karate club that can be used as a guide in structuring the organizational structure of a karate club in a school in Medan.

2. Structure of identification of talent in the karate sports branch, which will be trialled in small groups, to determine the level of accuracy of instruments in recruiting giftedness for karate sports. And it is hoped that this instrument will be a guide in the nursery program for prospective athletes in karate.

3. The curriculum curriculum for the karate school sports club, with this curriculum the nursery program and the formation of karate sports can be measured and planned well.

4. As the speaker at the national seminar on the results of a research conducted by the Medan State University research institute in 2017.

5. Data on the results of the trial of the giftedness instrument for small group karate sports.

\section{Conclusions And Suggestion}

The main text should be written using Times New Roman, 10pt, fully justified. Italics can be used for emphasis and bold typeset should be avoided.

\section{$5.1 \quad$ Conclusion}

From the research activities entitled the development of a karate club model development in Medan's junior high school, it has resulted in the form of a karate club organizational structure that can be used as a guideline for the karate club, in building a karate club in terms of organization. This research activity has also compiled a special gift test instrument for karate sports which is still in the small group trial stage. It is expected that this giftedness test instrument can be used as a guideline for the club in capturing the seeds of potential athletes in their respective schools. In developing the karate club training program this research activity 
has also compiled a karate curriculum that can be used to assist trainers in developing training programs.

\section{$5.2 \quad$ Suggestion}

This research must continue in order to narrow the coaching model for the medan secondary school karate club.

\section{References}

[1] Arikunto, S.: Prosedur Penelitian:Suatu Pendekatan Praktek (2002)

[2] Baumgartner, T A., Jackson, AS.: Measurements for Evaluation in Physical Education and Exercises Science (1995)

[3] Baumgartner, T A., at al.: Measurements for Evaluation in Physical Education and Exercises Science (2007)

[4] Bompa, T.O.: Theory and Methodology of Training The Key to Athletic Performance. (1994)

[5] Collins, D.R., Hodges, P.B.: AComprehensive Guide to Sports Skills Tests and Measurement (1978)

[6] Gall, MD., Gall, JP., Borg, WR.: Educational Research An Introduction (2003)

[7] Hoye, R., et.al.: Sport Management: Principles and Applications (2006)

[8] Lutan, Rusli.: Pedoman Perencanaan Pembinaan Olahraga (2013)

[9] Miller, D. K.: Measurement by The Physical Educator Why and How

[10] Nossek, J.: General Theory of Training (1982)

[11] Nurhasan.: Tes dan Pengukuran dalam Pendidikan Jasmani (2001)

[12] Sugiyono.: Metode Penelitian Pendidikan; Pendekatan Kuantitatif, Kualitatif dan R\&D (2006) 